\title{
Separation of Ownership and Control in Corporate Governance
}

\author{
Ahmad Alsharqawi * \\ School of Law, Applied Science Private University, Amman- Jordan \\ Abed Alkarim Alsharqawi \\ School of Law, Mutah University (Part Time), Amman_Jordan
}

The research is financed by Applied Science Private University. Amman- Jordan

\begin{abstract}
The Prevalence of Institutional Investors and their Growing Activism as Owners of Modern Corporations have had an Impact on Corporate Governance Structures Worldwide.This research will critically discuss the above statement in light of the ongoing debate on the phenomenon of separation of ownership and control.To achieve this we divide the research into six sections. The three major sections of the main body of this research consist of Corporate Governance Issues, the damaging effect of limited liability Companies and the effectiveness of shareholders as governors. The research has a suitable conclusion at the end.
\end{abstract}

Keywords: Corporate Governance, limited liability Companies, separation of ownership and control.

DOI: $10.7176 / J L P G / 84-07$

Publication date: April 30 2019

\section{Introduction}

The separation between the ownership and control of the limited company is the subject of longstanding debate. Many feel that the management of a company are not sufficiently incentivised to ensure the company is responsibly managed and hence are encouraged to take excessive risk. ${ }^{1}$ Shareholders generally have little input into the management of the company and are thought to be predominately concerned with increasing the value of their investment. $^{2}$

It is against this backdrop that corporate governance has developed, ensuring that the management of a company do not take excessive risks and run the company with due care and skill. ${ }^{3}$ The institutional investor is typically a financial institution, such as a pension or trust fund seeking to increase the value of the fund. Their knowledge of finance, the industry and corporations in which they invest has developed into the concept that shareholders could engage with the management of the corporation, helping to ensure that the company is managed in a responsible manner. ${ }^{4}$

Some consider that institutional investors have become more active in their oversight role which has had an impact on global governance standards. Others would argue that codes such as the Stewardship Code 2012 (SC) require institutional investors to play a more active stewardship role and thus increase the governance of the corporation. Nonetheless, the SC has been heavily criticised for the conflicts of interests that it creates. In addition, there is no detail within the code in regard to the action that institutional investors should take in the event of excessive risk taking. ${ }^{5}$

The research proceeds in six sections. the next section review issues in corporate governance. Section three the damaging effect of limited liability Companies. Section four the literature reviews through the effectiveness of shareholders as governors. Section five legislations like regulations that companies within the UK and America. The research has a suitable conclusion in the final section.

\section{Corporate Governance Issues}

Corporate governance has taken many different forms throughout history although it appears to have no precise definition. ${ }^{6}$ The majority of the definitions focus the governance internally within the organisation as opposed to external oversight. ${ }^{7}$ More recently, there has been a move toward external oversight functions seeking a greater level of accountability within organisations, where governance has become intertwined with principles of

\footnotetext{
${ }^{1}$ Monks R, and Minow N, Corporate Governance (5th edn, Wiley Publishing 2011) 7.

${ }^{2}$ Paddy Ireland, 'Limited liability, shareholder rights and the problem of corporate irresponsibility' (2010) 34 Cambridge Journal of Economics 837, 837.

${ }^{3}$ Stephen Bloomfield, Theory and Practice of Corporate Governance: An Integrated Approach

(Cambridge University Press 2013) 10.

${ }^{4}$ David Walker, A review of corporate governance in UK banks and other financial industry entities: Final Recommendations $(2009)<$ http://webarchive.nationalarchives.gov.uk/+/http:/www.hm-treasury.gov.uk/walker_review_information.htm>accessed 7 April 2016.

${ }^{5}$ Andreas Jansson, 'No Exit: The Logic of Defensive Shareholder Activism' (2014)10 Corporate Board: Role, Duties \& Composition 16, 29. 29.

${ }^{6}$ Stephen Bloomfield, Theory and Practice of Corporate Governance: An Integrated Approach

(Cambridge University Press 2013) 10.

${ }^{7}$ OECD, Principles of Corporate Governance (Paris: OECD, 1999).
} 
corporate social responsibility. ${ }^{1}$ The International Institute for Sustainable Development (IISD) define corporate social responsibility (CSR) as promoting "business accountability to a wide range of stakeholders, besides shareholders and investors". ${ }^{2}$ They identify that government intervention through legislation and regulation is outdated, expensive and thus there is a need for voluntary and non-regulatory initiatives to effect greater governance of the corporate form. ${ }^{3}$ Ironically, the UK government implemented statutory recognition of the CSR concept through section 172 Companies Act 2006, identifying the broad range of external stakeholders that directors must now consider as part of their director duties. The non-exhaustive list incorporates employees; creditors and suppliers; community and environment; the company and its shareholders. ${ }^{4}$ Notably the institutional investors are deemed to offer a greater level of oversight of corporations than regulators have previously managed. Thus ensuring that corporations are managed in a manner that is for the benefit of society generally as opposed to the costs that have been born under the concept of limited liability.

The creation of limited liability effectively separated a company's ownership from its control limiting the liability of the investor to the extent of their shareholding. ${ }^{5}$ This combined with the development of the rule in Foss v Harbottle, making the company the only rightful claimant in any wrong committed against it, ${ }^{6}$ created significant difficulties in respect of how companies with limited liability status could be effectively controlled. Recognition of the corporate form as a separate legal entity has prevented the courts from looking to either the members or the director's for reparation when the company had caused damage. All too frequently, significant damage or harm to individuals or the environment has gone without any form of reparation.

Cases such as Adams v Cape Industries Plc highlight the effects on employees who have suffered harm but were prevented from seeking redress due to the limited liability status of the company affording it a separate legal status from its parent holdings. ${ }^{7}$ Furthermore, the case also demonstrates the effects of global trading and the jurisdictional issues this brings. ${ }^{8}$ Unfortunately, cases such as these are not isolated, and whilst in Chandler v Cape plc the court held the parent company liable for the torts of its subsidiary that had ceased trading, such outcome is the exception rather than the norm. ${ }^{9}$ The courts have generally refused to accept that the corporate entity with a wholly owned subsidiary ought to be held accountable for the actions of the subsidiary. Whilst Chandler appears to allow the veil of the corporation to be lifted in instances of tort, the reality is that this will only be done in instances where the parent has assumed such responsibility under principles of agency. ${ }^{10}$ The arguments against the corporate entity escaping liability for its debts or actions have been waging since the conception of limited liability and separate legal personality status. ${ }^{11}$ Nonetheless, they have been dismissed on account of the perceived economic benefits that are deemed to outweigh any negatives that companies bring with them. ${ }^{12}$

\section{Damaging Effect of Limited Liability}

The lack of accountability and potential damage that large organisations may cause can far exceed their economic benefit. The recent example of the BP oil spill demonstrates the devastating effect that companies can have on the environment through poor risk management, shortcuts, equipment failure and poor management decisions. ${ }^{13}$ The true extent of the damage arising from the oil spill is unlikely to be determined for many years to come. Whilst BP have extended their efforts to repair the damage beyond mere legal compliance, it is unlikely that they will be able to fully repair the damage caused by the spill. ${ }^{14}$ It is possible to view the BP oil spill as a major success for corporate accountability as BP have accepted the full extent of the cost of the clean-up. In addition, those responsible for the spill are likely to be subject to civil and criminal charges. Nonetheless in the Exxon Valdez oil spill that occurred in 1964 leading to a jury awarding \$5 billion in punitive damages, this was undermined when it was reduced on

\footnotetext{
${ }^{1}$ ASX Corporate Governance Council, Corporate Governance Principles and Recommendations 3rd Edition (2014) Australian Securities Exchange $<$ http://www.asx.com.au/documents/asx-compliance/cgc-principles-and-recommendations-3rd-edn.pdf $>$ accessed 2 April 2016 , 3.

${ }^{2}$ International Institute for Sustainable Development, 'Corporate Social Responsibility' (2013) IISD

$<$ http://www.iisd.org/business/issues/sr.aspx> accessed 28 March 2016.

${ }^{3}$ Ibid.

${ }^{4}$ Companies Act 2006, section 172.

${ }^{5}$ Salomon v Salomon \& Co Ltd [1896] UKHL 1

${ }^{6}$ Foss v Harbottle (1843) 67 ER 189

${ }^{7}$ Adams v Cape Industries Plc [1990] Ch 433

${ }^{8}$ Ibid.

${ }^{9}$ Chandler v Cape plc [2012] EWCA Civ 525

${ }^{10}$ Derek French Stephen Mayson and Christopher Ryan, Mayson, French \& Ryan on Company Law (32nd edn, Oxford University Press 2015) 150 .

${ }^{11}$ Dan Plesch and Stephanie Blankenburg, 'How to Make Corporations Accountable' (2007) Institute of Employment Rights

$<$ http://www.cisd.soas.ac.uk/Files/docs/5675906-howtomakecorporationsaccountable.pdf $>$ accessed 30 March $2016,7$.

12 Ibid.

${ }^{13}$ John Broder, 'BP Shortcuts Led to Gulf Oil Spill, Report Says ' (2011) New York Times, September 14

$<$ http://www.nytimes.com/2011/09/15/science/earth/15spill.html?_r=0> accessed 30 March 2016.

${ }^{14}$ Ibid.
} 
appeal to a mere $\$ 500$ million. ${ }^{1}$

The argument against limited liability is stronger where management has lied in respect of the environmental conformity of their product as deliberate and continued deception to both authorities and consumers. ${ }^{2}$ Volkswagen suffered substantial and ongoing losses as a result of this deception that was deemed acceptable at the time as it believed other car manufacturers were undertaking similar processes ${ }^{3}$ The banks and financial institutions were also guilty of deception in the lead up to the financial crisis. Loan securities that represented high risk of nonrepayment were sold on as high quality investments. The regulator and many of the traders had no concept of the true nature of the investment that was being sold; they had been deceived. ${ }^{4}$ The damage far exceeded any losses to shareholders but extended from job losses to depleted pension funds, damage to the economy and loss to shareholders etc. Whilst those in support of limited liability identify that those responsible for the companies' actions are generally liable in tort, in reality, there are a few that are truly held to account and they have less resources available than the corporations to rectify the damage caused. ${ }^{5}$

Tort operates to protect 'fundamental human interests' and thus seeks to protect human health, environmental damage and also incorporates damage to property. ${ }^{6}$ The failure to remove the protection of limited liability for a company's actions under tort is defended on the basis that the agents themselves, i.e., the directors or managers would be held personally liable for their actions. ${ }^{7}$ While vicarious liability can ensure that the company is liable for the acts of its employees, there are a number of issues that pursuing an action of torts creates. The approach of the courts in making the individual tortfeasor personally liable is in direct conflict with limited liability status as demonstrated in Williams v Natural Life Health Foods. ${ }^{8}$ The sole trader with limited liability status had made negligent misstatements and the House of Lords ruled the director to be an individual who had contracted on behalf of the company and hence could not be personally liable. This is an odd distinction to make and is perceived as a further attempt to protect the status of limited liability unjustly.

Limited liability is not available for the smaller company seeking credit as the banks generally require the director's personal assets as security in the event of non-payment. Limited liability is necessary as a means of attracting and maintaining investment but there should be greater limits placed on its availability. Companies that are wholly owned by corporate forms, either as joint venture or as single company, have been afforded the protection of limited liability. Adams v Cape Industries Plc was particularly criticised as it was perceived as enabling a parent company to set up a poorly funded subsidiary which undertook activities likely to cause harm to employees and the environment.

\section{The Effectiveness of Shareholders as Governors \\ 4.1 The Berle Dodd Debate}

Shareholders as owners of the company with the power to appoint and remove directors were once considered to be effective as ultimate controllers of the company. Cases such as Dodge v. Ford Motor Co demonstrate the conflicts that are created in asking shareholders to implement effective corporate governance. ${ }^{9}$ Here, the company wanted to re-invest profits and grow the business, whilst the shareholders were more concerned with profit and successfully pursued an action for non-payment of special dividends. ${ }^{10}$ Shareholders are investors seeking a return on their investment and their losses are limited to the value of their shareholding. ${ }^{11}$ Cases such as this raise criticisms that the limited liability status is little more than "a political construct developed to accommodate and protect the rentier investor". ${ }^{12}$ This was not the intention of Adolf Berle when he anticipated that shareholders could have greater control of the corporation and instil governance as an internal mechanism. ${ }^{13}$ Berle anticipated that the shareholder would be the employees and the management and thus would have sufficient connection to

\footnotetext{
${ }^{1}$ Lynn Sarko, 'Litigation History' (2007) Exxon Qualified Settlement Fund

$<$ http://www.exspill.com/News/LitigationHistory/tabid/1918/Default.aspx> accessed 30 March 2016.

2 John Gapper, 'Volkswagen's deception is a warning to every company' (2015) Financial Times, 23 September

$<$ http://www.ft.com/cms/s/0/9e4a72a2-2f8c-11e5-91ac-a5e17d9b4cff.html\#axzz44PJJs19x> accessed 30 March 2016.

${ }^{3}$ Ibid

${ }^{4}$ Alford R, ‘Some Help In Understanding Britain’s Banking Crisis, 2007 - 09' (2011) London School of Economics Special Paper $193 / 2011$

$<$ http://www.lse.ac.uk/fmg/workingPapers/specialPapers/PDF/SP193.pdf> accessed 29 March 2016, 16.

${ }^{5}$ Stephanie Blankenburg and Dan Plesch, 'Corporate Rights and Responsibilities: Restoring Legal Accountability' [2007] Royal Society for the Encouragement of Arts 1, <http://eprints.soas.ac.uk/5689/> (accessed 30 March 2016), 2.

${ }^{6}$ Christian Witting, Street on Torts (14th edn, Oxford University Press 2015) 4.

${ }^{7}$ Paul Davies and Sarah Worthington, Gower and Davies' Principles of Modern Company Law (9th edition, Sweet \& Maxwell, 2012) [2.4].

${ }^{8}$ Williams v Natural Life Health Foods [1998] 1 W.L.R. 830

${ }^{9}$ Dodge v. Ford Motor Co (1919) 170 N.W. 668

${ }^{10}$ Ibid.

${ }^{11}$ Derek French Stephen Mayson and Christopher Ryan, Mayson, French \& Ryan on Company Law (32nd edn, Oxford University Press 2015) 125

12 Paddy Ireland, 'Limited liability, shareholder rights and the problem of corporate irresponsibility' (2010) 34 Cambridge Journal of Economics 837, 837.

${ }^{13}$ Fenner Stewart , 'Berle's Conception of Shareholder Primacy: A Forgotten Perspective For Reconsideration During the Rise of Finance' (2011) 34 Seattle University Law Review 1457,
} 
the company to influence how it was operated. ${ }^{1}$

Merick Dodd identified that corporations needed to be held "accountable to the society in which they operate" and the shareholder model that operated on principles of agency as opposed to a fiduciary nature was ineffective. ${ }^{2}$ There has been considerable criticism of the broader stakeholder approach implemented into the Companies Act 2006 ranging from their lack of enforceability by the various stakeholders to their inability to deal with competing and often conflicting interests. ${ }^{3}$ Since this time, there has been a greater focus on implementation of governance codes seeking greater disclosure and looking to enhance the role of the institutional investor in the company activities. $^{4}$

\subsection{Why Institutional Investors?}

Institutional investors have been chosen for their knowledge of the industry and their large shareholding, which gives them the ability to exert influence in the day-to-day activities of the company. ${ }^{5} \mathrm{~A}$ key part of their oversight may involve sitting on the board of the company as a non-executive director where it would be possible to exert direct influence. Whilst their knowledge of the industry would enable oversight to a certain extent it is unlikely to remove the possibility of the investor being deceived as to the risks that the company was taking. The Libor scandal being a particularly damaging and costly scandal to both bank image and share price. Such scandal, it is argued is unlikely to have been uncovered by an investor.

Initiatives requiring greater oversight of companies by institutional investors have also been criticised on the basis that they create a conflict of interests. The purpose of a pension fund is to create value for its fund holders and thus the fund holder must look to increase its value. ${ }^{6}$ Conflicts can also be found in different classes of shareholdings that an institutional investor may hold, sitting on the board of two competing companies is likely to raise issues of insider trading. Further issues are raised by the activity of an institutional investor in respect of negative publicity that this could create and the effect that this can have on a company's overall health and share price $^{7}$

The debate between Berle and Dodd shareholder and stakeholder theories of corporate governance during the 1930s are indicative of the debate that continues to this day. It is perhaps of little surprise that following the global financial crisis of 2007, governments throughout the world have sought to implement both shareholder and stakeholder models of corporate governance that appear to incorporate both Berle and Dodd's governance models. This paper argues that neither the shareholder or stakeholder model has been able to address the issue of ensuring greater accountability. It is submitted that this will only be achieved by making the company's controllers more accountable for its wrongdoing.

Whilst Keay identifies many weaknesses in the shareholder primacy model, he identifies one as being particularly problematic. ${ }^{8}$ This is the continued focus on increasing company wealth and share value and it is this continued focus that in turn promotes short-termism and encourages riskier activity. ${ }^{9}$ Such activity was evident in the banking sector prior to the financial crisis. ${ }^{10}$ The financial crisis of 2007 significantly undermines the shareholder primacy model as the crisis was effectively driven by the unwitting investors seeking the highest possible returns on their investments. It is arguable that institutional shareholders were deceived in the same manner as the regulator whereby their understanding of the risks and illegal activities that banks were undertaking did not occur until it was too late. ${ }^{11}$ Their focus, at the time and as it is now, was on growth and market share of the institution in relation to its competitors. ${ }^{12}$

Nonetheless, the financial crisis also demonstrates an inherent lack of accountability of senior management within Banks such as RBS and HBoS. Authorities failed to undertake any prosecutions in the UK "[b]ankers who

\footnotetext{
${ }^{1}$ Ibid.

${ }^{2}$ John Macintosh, 'The issues, effects and consequences of the Berle Dodd debate, 1931 - 1932' (1999) 24 Accounting, Organizations and Society 139, 145 .

${ }^{3}$ Andrew The Duty To Promote The Success Of The Company: Is It Fit For Purpose?' (2010) Working Paper Centre for Business Law and Practice, School of Law University of Leeds <http://ssrn.com/abstract=1662411 > accessed 29 March 2016, 13.

${ }^{4}$ Gregory Maassen, Frans van den Bosch and Henk Volberda, The importance of disclosure in corporate governance self-regulation across Europe: A review of the Winter Report and the EU Action Plan (2004) 1(2) International Journal of Disclosure and Governance $146,147$.

${ }^{5}$ Monks R, and Minow N, Corporate Governance (5th edn, Wiley Publishing 2011) pp. 111-115.

${ }^{6}$ John Coffee, 'Liquidity versus Control: The Institutional Investor as Corporate Monitor (1991) 91 Columbia Law Review $1277,1324$.

${ }^{7}$ Andreas Jansson, 'No Exit: The Logic of Defensive Shareholder Activism' (2014)10 Corporate Board: Role, Duties \& Composition 16, pp. $28-29$

${ }^{8}$ Andrew Keay, 'Ascertaining the corporate objective and entity maximisation and sustainability model' (2008) 71 Modern Law Review 663

$<$ http://ssrn.com/abstract=1889236> 12

${ }^{9}$ Ibid.

${ }^{10}$ Sue Konzelmann, Frank Wilkinson Mark Fovargue-Davies and Duncan Sankey, 'Governance, Regulation and Financial market Instability:

The Implications for Policy' (2009) Centre for Business Research, University of Cambridge Working Paper No. 392/2009,

$<$ http://www.cbr.cam.ac.uk/pdf/WP392.pdf> accessed 29 March 2016, 39.

${ }^{11}$ HM Treasury, 'A New Approach to Financial Regulation: Judgement Focus and Stability' (Cm 7874, 2010) [1.7].

${ }^{12}$ Hugh Jones, 'Banks have not fully learned lessons from Libor Scandal - UK Watchdog' (2015) Reuters 29 July

$<$ http://uk.reuters.com/article/uk-britain-markets-idUKKCN0Q30XB20150729> accessed 31 March 2016.
} 
had made the most catastrophic mistakes walked away with huge payouts and pensions". ${ }^{1}$ There was no mechanism was in place to hold those who had contributed to the collapse of the financial markets to account. Legislation that was implemented some five years after the financial crisis, seeking to hold those in key banking positions liable for their reckless decision-making is a step in the right direction. ${ }^{2}$ The changes in legislation only deals financial institutions and thus raises questions as to why directors of other large corporations that are recklessly managed are not currently held legally accountable, aside from the relatively few criminal sanctions that are in place. The UK Financial Services (Banking Reform) Act 2013 fails to address the actions of the directors and chief executives that led them to take excessive risks leading to the financial crisis in 2007 as sanctions cannot be imposed retrospectively. Moreover, concerns have been raised on the effect of the criminal sanctions on the basis that it is difficult to establish responsibility of particular individuals who have broadly defined responsibilities and are also likely to have deep pockets to defend any charges. ${ }^{3}$

\subsection{Limitations on Shareholder Intervention}

A common principle of company law is that directors should be free in their decision-making and the only limits to this are manifested in the company's constitution. ${ }^{4}$ Even where a majority shareholder has wanted to prevent an activity of the company, the courts have ruled against such interference. Barwick CJ stated that "Directors who are minded to do something which in their honest view is for the benefit of the company are not to be restrained because a majority shareholder or shareholders holding a majority of shares in the company do not want the directors so to act". 5 This raises doubt as to the extent of influence that a major shareholder such as an institutional investor can have if they want to prevent the directors from undertaking a particular activity. The difficulty of making a derivative claim on behalf of the company is further proof of the reluctance of the courts and the legislator to interfere with the running of the company. ${ }^{6}$ This is due to the damaging effect that such litigation can have on the overall health of the company. ${ }^{7}$

There are many limits on the ability of the institutional investor to deal with poor practices within large international companies. The above statement refers to the "growing activism" of institutional investors which has brought a dramatic change in the "corporate governance structures world wide". This is despite conflicts of interest, a lack of knowledge, and the effect that intervention can have on a company; notwithstanding the potential for knowledge transfer amounting to insider dealing. Addressing the issues in relation to shareholders this paper has looked at other forms of governance that have also been put into place that seek companies to look beyond the shareholder to the wider stakeholder and noted that this too is beset with issues. It has also looked at the effect of limited liability on the responsibility of shareholders and questioned whether such status is validated. It is with this background that an exploration on the changes that have been implemented in corporate governance is undertaken.

To this end, it is noted that the principle focus of the changes relate to increased reporting appears to ensure that investors are as informed as possible in their decision making. Changes that Keay refers to as the principle move towards a new model of corporate governance modelled on "entity maximisation and sustainability" (EMS). ${ }^{8}$ The EMS governance model essentially involves a change of attitudes where companies avoid actions that can put the employees or the public in danger, delaying payment of creditors or embracing risky ventures purely to increase revenue. ${ }^{9}$ Whilst this is clearly an ideal, the ethical approach is subject to being undermined by basic economic principles of supply and demand and market forces. The decline of the UK Steel industry is a point in example, prices for steel manufacture are cheaper from China than can be achieved in the UK or much of Europe. ${ }^{10}$

\subsection{Greater Reporting}

Since the financial crisis, the UK government and many others and have implemented codes of corporate governance and stewardship aimed at ensuring corporations are more accountable. The Organisation for Economic Co-Operation and Development (OECD) issued a corporate governance code in 2010 asking multinationals to both have a knowledge of the environment their companies operate whilst also seeking to influence local

\footnotetext{
${ }^{1}$ The Rt Hon George Osborne, 'Statement on banking by the Chancellor of the Exchequer' (2011) HM Treasury 9 February $<$ https://www.gov.uk/government/news/statement-on-banking-by-the-chancellor-of-the-exchequer> accessed 31 March 2016.

${ }^{2}$ UK Financial Services (Banking Reform) Act 2013

3 Julia Black and David Kershaw, 'Criminalising Bank Managers' (2012) London School of Economics and Political Science Law and Financial Markets Project Briefing 1/13<https://www.lse.ac.uk) accessed 31 March 2016.

4 Towcester Racecourse Co Ltd v Racecourse Association Ltd [2003] 1 BCLC 260, per Patten J [19].

${ }^{5}$ Ashburton Oil NL v Alpha Minerals NL (1971) 123 CLR 614 per Barwick CJ at 620.

${ }^{6}$ Andrew Keay, 'An assessment of private enforcement actions for directors' breaches of duty’ (2014) 33(1) Civil Justice Quarterly 76, 86. Ibid.

${ }^{8}$ Andrew Keay, 'Ascertaining the corporate objective and entity maximisation and sustainability model' (2008) 71 Modern Law Review 663

$<$ http://ssrn.com/abstract=1889236> 32 .

${ }^{9}$ Ibid.

${ }^{10}$ Allister Heath, 'The tragic decline and fall of the UK's steel industry' (2016) The Telegraph 18 January

$<$ http://www.telegraph.co.uk/finance/economics/12106829/The-tragic-decline-and-fall-of-the-UKs-steel-industry.html $>$ accessed 1 April 2016.
} 
governments. ${ }^{1}$ It is the greater reporting requirements that appear to be having an impact on health and safety standards where goods are manufactured in poorer countries by multi-nationals. ${ }^{2}$ Nonetheless, there are many limitations on the effectiveness of these local interventions. ${ }^{3}$ Relatively recent reports into Primark and Apple identify that there are a multitude of standards in CSR. ${ }^{4}$ Company's site investigations to check CSR have been undermined with devastating consequences to both human life and the environment. Enhanced reporting requirements are however seen to encourage greater discussions on how corporations can be more accountable and socially responsible. It is arguable that the changes are slowly being implemented.

Increasing shareholder activation comes in the form of statements sent by fund managers to the corporations that they seek to monitor that they intend to pursue corporate governance goals. ${ }^{5}$ Such broad statement fails to give any detail as to the elements of corporate governance that they intend to pursue. If we look at the principles of $\mathrm{CSR}$, it is readily apparent that shareholder interests are incorporated within CSR. There is no statement how investors will address conflicting variables such as the interests of employees over that of the environment or supplier. Another factor that has failed to be considered is the impact of increased governance and regulation on the cost of production and the overall profitability.

How then does this fit with limited liability. Does governance supersede financial accountability? The answer is clearly no; however, if shareholders were made accountable for the extreme losses that corporations can suffer, it is likely that there would be a significant decline in investment. The government-enforced ring fencing of banks' toxic assets as a tool to restore confidence in the financial markets undermines the argument that this paper supports, namely that parents should be held responsible for their subsidiaries. ${ }^{6}$

\section{Legislation}

There are, however, a considerable amount of laws and regulations that companies within the UK and America have to adhere to in order to operate in developing countries. The ever-growing extra territorial nature of laws implemented through both the United States and the United Kingdom are likely to have far greater impact on companies than shareholder intervention alone. ${ }^{7}$ It is changes such as these that are effectively driving a cultural change where it is no longer acceptable for companies to abuse the status of limited liability. Will this approach prevent excessive risk taking and the next financial crisis? Leading academics agree that it is not possible to prevent financial crisis. Throughout history, financial crises have been driven by greed, deception and excessive risk taking. It has always been in the interest of institutional shareholders to monitor their shareholdings, and thus, making them more involved in that process is in reality likely to have a very limited effect. CSR and increased governance have its place but only for a short while. As prosperity ensues, companies will challenge the restrictions as affecting growth and the cycle will resume. Challenges to limited liability status are becoming less robust though as laws and controls increase. Unless some radical change occurs to the way business is financed and operated, this is unlikely to change in the near future.

\section{Conclusion}

Throughout history, the approach of corporate governance has altered to reflect the perceived risk at that time. Using institutional investors as a method of overseeing corporations was introduced following the financial crisis. The aim of this approach is to steer corporations away from riskier activity that can impact health, wealth and the environment. Nonetheless, there are clear indications that such approach is inherently flawed. Perhaps the biggest issue is in relation to their conflicting interests. Their primary incentive is to increase their fund value and hence they are unlikely to take any action that will undermine this. In terms of influencing a corporation's activities, they are unlikely to have any real knowledge of the day-to-day operations of the company. Deception played a key role in the financial crisis, in which regulators and investors were equally deceived. What is evident, is that there is fundamental lack of accountability within organisations and itis this that encourages excessive risk taking. Limited

\footnotetext{
${ }^{1}$ Sylvie Avignon, 'Do the codes of conduct become tools of international management? The lawyer view' (2007) 3 International Business Law Journal 335, 339.

${ }^{2}$ Doreen McBarnet and Patrick Schmidt, 'Corporate Accountability through Creative Enforcement: Human Rights, the Alien Tort Claims Act and the Limits of Legal Impunity’ in D McBarnet, A Voiculescu and T Campbell (eds) The New Corporate Accountability: Corporate Social Responsibility and the Law (Cambridge University Press 2009).

${ }^{3}$ Christine Parker, 'Meta-regulation: Legal Accountability for Corporate Social Responsibility' in D McBarnet, A Voiculescu and T Campbell (eds), The New Corporate Accountability: Corporate Social Responsibility and the Law (Cambridge University Press 2007$) 237$.

${ }^{4}$ Agence Frence Presse, 'Apple under fire again for working conditions at Chinese factories' (2014) The Guardian 19 December $<$ Apple under fire again for working conditions at Chinese factories> accessed 1 April 2015.

${ }^{5}$ Yaron Nili, 'The Evolving Landscape of Shareholder Activism: Developments and Potential Actions' (2015)

Harvard Law School Forum on Corporate Governance and Financial Regulation 24 March <https://corpgov.law.harvard.edu/2015/03/24/theevolving-landscape-of-shareholder-activism-developments-and-potential-actions/> accessed 1 April 2016.

6 Deloitte Financial Services, UK Bank Ring-Fencing - What Goes Where? (2014) Mondaq 29 July $<$ http://www.mondaq.com/x/331028/Commodities+Derivatives+Stock+Exchanges/UK+Bank+RingFencing + What + Goes + Where $>$ accessed 1 April 2016

${ }^{7}$ Fred Yeager and others, 'US legislation designed to improve corporate governance: an exploration' (2012) 33(1) Company Lawyer $25,25$.
} 
liability does undermine corporate accountability but continues to be perceived as a valid mechanism for encouraging investment and thus is unlikely to be removed.

\section{References}

Agence Frence Presse, ‘Apple under fire again for working conditions at Chinese factories' (2014) The Guardian 19 December <Apple under fire again for working conditions at Chinese factories> accessed 1 April 2015.

Allister Heath, 'The tragic decline and fall of the UK's steel industry' (2016) The Telegraph 18 January $<$ http://www.telegraph.co.uk/finance/economics/12106829/The-tragic-decline-and-fall-of-the-UKs-steelindustry.html> accessed 1 April 2016.

ASX Corporate Governance Council, Corporate Governance Principles and Recommendations 3rd Edition (2014) Australian Securities Exchange <http://www.asx.com.au/documents/asx-compliance/cgc-principles-andrecommendations-3rd-edn.pdf $>$ accessed 2 April 2016.

Avignon S, 'Do the codes of conduct become tools of international management? The lawyer view' (2007) 3 International Business Law Journal 335.

Black J and Kershaw D, 'Criminalising Bank Managers' (2012) London School of Economics and Political Science Law and Financial Markets Project Briefing 1/13<https://www.lse.ac.uk) accessed 31 March 2016.

Blankenburg S and Plesch D, 'Corporate Rights and Responsibilities: Restoring Legal Accountability' [2007] Royal Society for the Encouragement of Arts 1, <http://eprints.soas.ac.uk/5689/> (accessed 30 March 2016),

Bloomfield, Theory and Practice of Corporate Governance: An Integrated Approach (Cambridge University Press, 2013) 10.

Broder J, 'BP Shortcuts Led to Gulf Oil Spill, Report Says ' (2011) New York Times, September 14 $<$ http://www.nytimes.com/2011/09/15/science/earth/15spill.html?_r=0> accessed 30 March 2016.

Coffee J, 'Liquidity versus Control: The Institutional Investor as Corporate Monitor (1991) 91 Columbia Law Review 1277.

Davies P and Worthington S, Gower and Davies' Principles of Modern Company Law (9th edition, Sweet \& Maxwell 2012).

Deloitte Financial Services, UK Bank Ring-Fencing - What Goes Where? (2014) Mondaq 29 July $<$ http://www.mondaq.com/x/331028/Commodities+Derivatives+Stock+Exchanges/UK + Bank+RingFencing+What+Goes+Where $>$ accessed 1 April 2016

French D, Mayson S and Ryan C, Mayson, French \& Ryan on Company Law (32nd edn, Oxford University Press 2015).

Gapper J, 'Volkswagen's deception is a warning to every company' (2015) Financial Times, 23 September $<$ http://www.ft.com/cms/s/0/9e4a72a2-2f8c-11e5-91ac-a5e17d9b4cff.html\#axzz44PJJs19x> accessed 30 March 2016.

HM Treasury, 'A New Approach to Financial Regulation: Judgement Focus and Stability' (Cm 7874, 2010).

International Institute for Sustainable Development, 'Corporate Social Responsibility' (2013) IISD $<$ http://www.iisd.org/business/issues/sr.aspx> accessed 28 March 2016.

Ireland P, 'Limited liability, shareholder rights and the problem of corporate irresponsibility' (2010) 34 Cambridge Journal of Economics 837

Jansson A, 'No Exit: The Logic of Defensive Shareholder Activism' (2014)10 Corporate Board: Role, Duties \& Composition 16.

Jones H, 'Banks have not fully learned lessons from Libor Scandal - UK Watchdog' (2015) Reuters 29 July $<$ http://uk.reuters.com/article/uk-britain-markets-idUKKCN0Q30XB20150729> accessed 31 March 2016.

Keay A, 'An assessment of private enforcement actions for directors' breaches of duty' (2014) 33(1) Civil Justice Quarterly 76.

Keay A, 'Ascertaining the corporate objective and entity maximisation and sustainability model' (2008) 71 Modern Law Review $663<$ http://ssrn.com/abstract=1889236> 12.

Keay A, 'The Duty To Promote The Success Of The Company: Is It Fit For Purpose?' (2010) Working Paper Centre for Business Law and Practice, School of Law University of Leeds $<$ http://ssrn.com/abstract=1662411 $>$ accessed 29 March 2016, 1.

Konzelmann S, Wilkinson F, Fovargue-Davies M, and Sankey D, 'Governance, Regulation and Financial market Instability: The Implications for Policy’ (2009) Centre for Business Research, University of Cambridge Working Paper No. 392/2009, <http://www.cbr.cam.ac.uk/pdf/WP392.pdf> accessed 29 March 2016.

Maassen G, van den Bosch F and Volberda H, 'The importance of disclosure in corporate governance selfregulation across Europe: A review of the Winter Report and the EU Action Plan' (2004) 1(2) International Journal of Disclosure and Governance 146.

Macintosh J, 'The issues, effects and consequences of the Berle Dodd debate, 1931 - 1932' (1999) 24 Accounting, Organizations and Society 139.

McBarnet D and Schmidt P, 'Corporate Accountability through Creative Enforcement: Human Rights, the Alien 
Tort Claims Act and the Limits of Legal Impunity' in D McBarnet, A Voiculescu and T Campbell (eds) The New Corporate Accountability: Corporate Social Responsibility and the Law (Cambridge University Press 2009).

Monks R, and Minow N, Corporate Governance (5th edn, Wiley Publishing 2011).

OECD, Principles of Corporate Governance (Paris: OECD, 1999).

Parker C, 'Meta-regulation: Legal Accountability for Corporate Social Responsibility' in D McBarnet, A Voiculescu and T Campbell (eds), The New Corporate Accountability: Corporate Social Responsibility and the Law (Cambridge University Press 2007) 237

Plesch D and Blankenburg S, 'How to Make Corporations Accountable' (2007) Institute of Employment Rights $<$ http://www.cisd.soas.ac.uk/Files/docs/5675906-howtomakecorporationsaccountable.pdf $>$ accessed 30 March 2016.

Sarko L, 'Litigation History' (2007) Exxon Qualified Settlement Fund $<$ http://www.exspill.com/News/LitigationHistory/tabid/1918/Default.aspx> accessed 30 March 2016.

The Rt Hon George Osborne, 'Statement on banking by the Chancellor of the Exchequer' (2011) HM Treasury 9 February <https://www.gov.uk/government/news/statement-on-banking-by-the-chancellor-of-the-exchequer> accessed 31 March 2016.

Walker D, A review of corporate governance in UK banks and other financial industry entities: Final Recommendations (2009) <http://webarchive.nationalarchives.gov.uk/+ /http:/www.hmtreasury.gov.uk/walker_review_information.htm> accessed 7 April 2016.

Yaron Nili, 'The Evolving Landscape of Shareholder Activism: Developments and Potential Actions' (2015) Harvard Law School Forum on Corporate Governance and Financial Regulation 24 March $<$ https://corpgov.law.harvard.edu/2015/03/24/the-evolving-landscape-of-shareholder-activismdevelopments-and-potential-actions/> accessed 1 April 2016.

Yeager F and others, 'US legislation designed to improve corporate governance: an exploration' (2012) 33(1) Company Lawyer 25.

Statute

Companies Act 2006

OECD Corporate Governance Code 2010

Stewardship Code 2012

UK Financial Services (Banking Reform) Act 2013

Cases

Adams v Cape Industries Plc [1990] Ch 433

Ashburton Oil NL v Alpha Minerals NL (1971) 123 CLR 614 per Barwick CJ at 620

Chandler v Cape plc [2012] EWCA Civ 525

Dodge v. Ford Motor Co (1919) 170 N.W. 668

Foss v Harbottle (1843) 67 ER 189

Salomon v Salomon \& Co Ltd [1896] UKHL 1

Towcester Racecourse Co Ltd v Racecourse Association Ltd [2003] 1 BCLC 260.

Williams v Natural Life Health Foods [1998] 1 W.L.R. 830 